PART 2

The Publicity Stage 
Henriette Goldwyn and Suzan van Dijk - 9789004304789 Downloaded from Brill.com04/26/2023 11:52:54AM via free access 


\title{
Madame Du Noyer Presenting and Re-presenting the Peace of Utrecht
}

\author{
Henriette Goldwyn and Suzan van Dijk
}

On Thursday, 27 April 1713, Mme Du Noyer, also known as Anne-Marguerite Petit, wrote in her periodical, the Quintessence des nouvelles historiques, critiques, politiques, morales et galantes:' 'On apprend de Paris, par des lettres datées du 21 de ce mois que la conclusion et la signature de la paix y a répandu une grande joie surtout parmi le peuple et les négociants'.2 In several previous announcements she had alluded to this much-awaited event and the criss-crossing of borders by dignitaries carrying the news to several of the monarchs who were the key players in this peace treaty. On 20 April, she wrote: 'On apprend de Londres que Mr. de Saint Jean, secrétaire de l'Ambassade d'Angleterre, y est heureusement arrivé d'Utrecht, avec le Traité d'Utrecht, qu'il est allé porter à la Reine'; earlier she had mentioned: 'On apprend d'Utrecht que Mr. le Commandeur de Béringant en est parti, pour aller porter au Roi de France l'agréable nouvelle de la Paix'. ${ }^{3}$

Mme Du Noyer's coverage of the Peace negotiations has unfortunately been overlooked by twentieth-century historians of the Treaty of Utrecht. Even in recent publications by Onnekink and De Bruin, who discuss Freschot's Histoire

1 La Quintessence des nouvelles historiques, critiques, politiques, morales et galantes (The Hague: Uytwerf, 1689-1730). Du Noyer was one of the successive editors of this biweekly: from 1711, taking over from Nicolas de Gueudeville, until her death in 1719. It was originally founded by Maximilien Lucas in The Hague (Jean Sgard, Dictionnaire des journaux 1600-1789, Edition électronique revue, corrigée et augmentée <http://dictionnaire-journaux.gazettesi8e.fr/>).

2 QN, nr. 34, 27 April 1713: 'We learn from Paris through letters dating to the 21st of this month that the conclusion and signature of the peace [treaty] has spread great joy among people and merchants'. Translations are by Henriette Goldwyn and Francesca M. Scott; spelling in French quotations has been modernized throughout.

3 QN, nr. 32, 20 April 1713: 'We learn from London that Mr. de Saint Jean, Secretary of the English Embassy, has arrived from Utrecht with the Treaty which he has taken to the Queen'; QN, $\mathrm{n}^{\mathrm{o}}$ 31, 17 April 1713: 'We learn from Utrecht that Mr. de Béringuant has left to carry the good news of this new peace to the King of France'.

(C) KONINKLIJKE BRILL NV, LEIDEN, 2015 | DOI 10.1163/9789004304789_007 
du Congrès et de la Paix d'Utrecht ${ }^{4}$ there is no mention of Du Noyer's earlier, twofold reporting of this unprecedented historic moment. Therefore, by taking into account Du Noyer's voice, we will consider her reporting techniques as they shed light on many historic, political and social events of her time, which are of particular interest to us. Focusing on the interrelation between diplomacy and performative culture in the public sphere, we will examine how her blending, mixing, rewriting and blurring texts and genres allow her to construct - through a sort of auto-plagiarism-a multi-layered narrative of the Peace of Utrecht. She actually composes a two-tier system of reporting the events, consisting of an immediate, day-to-day version, in the Quintessence, and a reworked, further developed narrative, reissued numerous times over the eighteenth century in her successful collection entitled Lettres historiques et galantes. ${ }^{5}$ Du Noyer's coverage of the negotiations in the Quintessence framed the Peace of Utrecht as an event with global consequences that implicated all the nations involved rather than two isolated powers. ${ }^{6}$ In the first issue of 1713 , her wishes are of a very generous nature: 'Nous ne saurions mieux commencer la première Quintessence de cette année qu'en faisant des vœux [....] même pour nos Ennemis. Fasse le Ciel qu'ils perdent bientôt un nom aussi odieux, et qu'une bonne Paix ou nos Victoires rendent le Calme à l'Europe et en fassent la sûreté. ${ }^{7}$ Du Noyer was aware of current events and wanted to show that the outcome of negotiations in Utrecht played out on a larger, cosmopolitan, pan-European and ideological scale, and affected the new 'balance of power' in Europe and beyond.

4 Casimir Freschot, Histoire du Congrès et de la Paix d'Utrecht, comme aussi de celle de Rastadt \& de Bade contenant les particularitez les plus remarquables \& les plus interessantes desdites Negociations depuis leur premiere ouverture jusqu'à la conclusion de la Paix Generale (Utrecht: Van Poolsum, 1716). This book is briefly discussed by David Onnekink, 'The Treaty of Utrecht 1713', in Peace was made here. The Treaties of Utrecht, Rastatt and Baden, 1713-1714, ed. Renger de Bruin and Maarten Brinkman (Petersberg: Michael Imhof Verlag, 2013), 66 (he gives 1715 as the publication date), and by David Onnekink and Renger de Bruin, De Vrede van Utrecht (1713) (Hilversum: Verloren, 2013), 98.

5 The successive volumes, sticking only loosely together, were published in 1704, 1708, 1710, 1711, $1712,1713,1717$. For some of them there were at least ten editions, the last one dating back to 1790. The one used here is the 1720 edition (Amsterdam: Brunel).

6 Realizing probably that this was 'the first conflict on a global scale' (Onnekink, 'The Treaty of Utrecht 1713,' 60; our italics).

7 QN, nr. 1, 2 January 1713: 'The best way to open the first Quintessence of this year is by formulating wishes $[\ldots .$.$] even for our enemies. Let us hope they will soon lose this awful name,$ and that either a good Peace or our Victories provide calm and security all over Europe'. 
Since previous issues of the Quintessence are difficult to locate, ${ }^{8}$ we can determine only with limited certainty that, at least from 3 October 1712 (nr. 79), she informed her network of European readers about the Peace process and all the activities taking place in the Utrecht town hall where the ambassadors met. For instance, she describes Strafford's trip back and forth from Utrecht to London; ${ }^{9}$ the death of the Prussian plenipotentiary Consbruch and his replacement by Kirchner in November, ${ }^{10}$ the illness of count of Tarouca of Portugal yet the magnificence of the festivities he organized to celebrate the birth of a prince early in January. ${ }^{11}$ In great detail she depicts the effervescence of the cosmopolitan atmosphere in Utrecht, which was, after all, a small town. But now French theatre was being performed, ${ }^{12}$ Queen Anne's birthday was being celebrated, ${ }^{13}$ and many other festivities and events were taking place. During this coverage of the negotiations - eight and a half months - she observes and presents all aspects of the peace process and the dignitaries involved. It seems probable that her Quintessence attracted an important number of readers beyond its regular audience, which would have been one of her main objectives, especially given the precarious state of her finance. ${ }^{14}$ This would also explain the eagerness with which she started publishing, one month after the Peace proclamation, in the sixth volume of her Lettres historiques et galantes: de deux dames de condition dont l'une était à Paris et l'autre en Province, the reworked version of the bulk of the material included in the Quintessence.

8 Collections of the Quintessence are incomplete: the most important one (at the Bibliothèque de l'Arsenal, Paris) which we consulted, does not possess any issues for the year 1712 before October.

QN, nr. 84, 20 October 1712-nr. 101, 19 December 1712.

$10 \quad$ QN, nr. 89, 7 November 1712-nr. 94, 24 November 1712.

11 QN, nr. 97, 5 December 1712-nr. 5, 16 January 1713.

12 QN, nr. 15, 20 February 1713.

13 QN, nr. 16, 23 February 1713.

14 This is illustrated by remarks of one of her rival reporters, the author of the Histoire amoureuse et badine du Congrès et de la Ville d'Utrecht who is supposed to be either Casimir Freschot (mentioned in n. 4; most current attribution) or Augustin Freschot (argued by Utrecht archivist Erik Tigelaar in his introduction to Roland Fagel's translation of this text: Amoureuze en pikante geschiedenis van het congres en de stad Utrecht. Hilversum: Verloren, 2013). The title page announces Liège: Le Doux, Weller, 1713; in fact, it was published in Utrecht (Weller: 1713). Freschot criticized Du Noyer for writing quickly out of sheer penury: 'ayant tous les jours à combattre contre la faim et la misère elle se sert des armes qu'elle croit les plus propres pour cela, c'est à savoir de sa plume' (11th letter, 254). About the authorship of the Histoire amoureuse et badine, see also Duchhardt's contribution to the present volume. 
This collection of fictional letters, the first part of which was published in 1704, stages two ladies, living in different cities and writing to each other about what is happening in their respective locations. ${ }^{15}$ In the beginning of the sixth volume, ${ }^{16}$ one of the ladies, coming from Aix-la-Chapelle, arrives in Utrecht, understanding that this is where everything is going to happen. She plans to inform her friend, who spends most of her time in Paris and is very curious to know all about it: 'parlons un peu premièrement du lieu où l'on travaille à cette Paix. Le nom en est devenu fameux. On ne parle que d'Utrecht dans toutes les conversations; et je voudrais bien pouvoir en parler à mon tour.. ${ }^{17}$ Her friend sends her information about the progress of the conference as well as anecdotes about the private activities and behaviour of those in Utrecht.

This fictional epistolary exchange, largely a rewriting of what had been published in the Quintessence, provides an interesting case illustrating the impact of this formidable event and the intelligent and fascinating use Du Noyer makes of it. Below, we discuss Du Noyer's authorship in relation to the two genres she practiced, in which the 'Peace of Utrecht' was central.

\section{Mme Du Noyer (Anne-Marguerite Petit)}

A Calvinist refugee, considered to be the first or one of the first women journalists in the French language to attain fame and notoriety, Mme Du Noyer ${ }^{18}$ (1663-1719) took up writing in the Netherlands where she established herself (around 1700) after the revocation of the Edict of Nantes. Taking advantage of the freedom of the press afforded by her newly adopted homeland, she contributed to the dissemination of current events not just to the Dutch readers but also to those in other European countries. Her role in the history of Frenchlanguage journalism under the old Regime went unjustly unrecognized for

15 Laurent Versini described it as an early version of what would become the genre of the epistolary novel. See Laurent Versini, Le roman épistolaire (Paris: PUF, 1979), 61.

16 In later editions the 'Utrecht letters' will be in vols. III and IV (see also n. 5).

17 LHG, Letter LXXXviII (from Paris), 290: let us talk first about the place where Peace is being prepared. The name has become famous. Everybody is speaking about Utrecht by now; and I would like being able to take part in these discussions'.

18 For more information on Mme Du Noyer, the revocation of the Edict of Nantes, consult the Introduction to the Mémoires de Mme du Noyer, ed. Henriette Goldwyn (Paris: Mercure de France, 2005). Incidentally, Marie-Antoinette's copy of the Mémoires is now at the Bibliothèque Nationale de France. 
many years. ${ }^{19}$ In addition to authoring memoires ${ }^{20}$ and the Lettres Historiques et Galantes, she also became the editor of the Quintessence des Nouvelles, after having briefly produced a monthly entitled Nouveau Mercure Galant des Cours de l'Europe. ${ }^{21}$

Joining some of her coreligionists in exile, Mme Du Noyer dedicated the latter part of her life to the periodical press which provided her with an income to support her daughter and grand-daughter in Voorburg, near The Hague, where she resided. French Huguenots in Holland produced a dissident press that combined journalism, news, editorial reporting, and they were able to articulate views that countered the tenets of monarchical absolutism and exposed the oppressive, exclusionary policies of Louis XIV. ${ }^{22}$ These broadsides, gazettes, 'mercures', spectators, letters, also called 'lardons', enjoyed considerable success in France, the true target of its production, distribution, and criticism. Versailles monitored these periodicals closely through its ambassador at The Hague, and it has been said that Vauban went so far as ordering the production of contre-lardons (counterlardons). ${ }^{23}$ While this production was vilified by some, others consumed it with relish, as Hans Bots indicates in his 'L'Echo de la Révocation dans les Provinces-Unies'.24

As a female journalist, Du Noyer was quite an exception during her time: she was successful in the sense that she managed to keep the Quintessence alive for eight years, until her death. Her Lettres historiques et galantes were reissued over the century, and copies of it were found in numerous eighteenthcentury private libraries in the Netherlands. ${ }^{25}$ Nancy O'Connor mentions

19 It was first discussed in Suzan van Dijk, 'Madame Du Noyer, ou comment tirer parti de son travail,' Documentatieblad Werkgroep Achttiende Eeuw 18 (1986): 15-21, and in Suzan van Dijk, Traces de femmes. Présence féminine dans le journalisme français du XVIII ${ }^{e}$ siècle (Maarssen: Holland University Press, 1988), the chapter entitled 'Madame Du Noyer, auteur de la Quintessence des Nouvelles, 1711-1719,' 85-133, in particular 128-132. Mémoires de Madame du $N^{* * *}$ écrits par elle-même (Cologne: P. Marteau, 1709-1710).

21 Nouveau Mercure Galant des Cours de l'Europe (The Hague: E. Foulque, Nov-Dec, 1710).

22 This press was studied in the series Etudes de l'Institut Pierre Bayle, directed by Hans Bots of the University of Nijmegen during the last decades of the twentieth century.

23 See p. 101 for an explanation of lardons.

24 'Pour une information plus franche et moins partiale les Français en restaient réduits aux gazettes de Hollande, dont une partie importante parut d'ailleurs en langue française.' Hans Bots, 'L'Echo de la Révocation dans les Provinces-Unies', in La Révocation de l'Edit de Nantes et le protestantisme français en 1685, ed. Roger Zuber and Laurent Theis (Paris: Société de l'Histoire du Protestantisme français, 1986), 281-298: 284.

25 And elsewhere probably, but evidence for the Netherlands is available about the LHG being included in twenty-nine private and public libraries in the Netherlands in the 
that the letters were used as a reliable source until well into the nineteenth century. ${ }^{26}$ Du Noyer has, however, suffered—like so many early modern women writers-from negative stereotyping and discriminatory remarks. ${ }^{27}$ Her name has been smeared, she has been mocked, and her work has been forgotten. Due to the emphasis placed on her unusual life and unorthodox personality, serious scientific research on her work is quite arduous. The authors of this paper have rectified this trend in earlier publications by underscoring her contribution and disseminating her work as an author of diverse and novel genres. A forerunner on many fronts, she was appreciated and recognized during her time. As an example, we can refer to Justus van Effen, the Dutch follower of Addison and Steele, who clearly was familiar with her work. At the time, he was also writing French language periodicals, publishing in The Hague, as Du Noyer did, ${ }^{28}$ and referred to her work in a positive way. ${ }^{29}$

eighteenth century. About this type of source see: Alicia C. Montoya, 'French and English women writers in Dutch library (auction) catalogues, 1700-1800. Some methodological considerations and preliminary results,' in 'I have heard aboutyou.' Foreign women's writing crossing the Dutch border: from Sappho to Selma Lagerlöf, ed. S. van Dijk et al. (Hilversum: Verloren, 2004), 182-216.

26 Nancy O'Connor, in the introduction to her edition of the LHG (Rennes: Presses Universitaires de Rennes, 2012), 9-29.

27 For instance, Louis Philipon de la Madelaine, in his Modèles de lettres sur divers sujets (1761) comments on her Lettres historiques et galantes in this very negative way: 'Les Lettres de Madame Du Noyer ne méritent pas qu'on s'y arrête. Ce n'est qu'un ramas assez insipide d'anecdotes apocryphes, de contes ridicules, d'aventures romanesques, où la bienséance et les mœurs ne sont que trop souvent révoltées' (45).

28 At the end of his life (1731-1735), he published in Dutch his famous Hollandsche Spectator (Dutch Spectator) and became one of the canonized Dutch eighteenth-century writers. See about his early French spectators S. van Dijk, 'Un "Spectateur” regarde les femmes: Justus van Effen,' in Traces de femmes, 21-55.

29 In his Misantrope he illustrates the Quintessence's popularity: "Les Enigmes sont si fort en vogue, qu'il est bien juste que j'en dise un mot. Dès qu'on met le pied dans une compagnie, 'Ah, Monsieur, ou Madame, vous dit-on, avez-vous deviné une telle Enigme du Mercure, ou de la Quintessence?' " (1 February 1712); speaking about 'women of genius', he takes Du Noyer as an example: 'Les femmes qui ont du génie saisissent d'abord le mot qu'il leur faut [...]. C'est ce style aisé du beau sexe qui nous sait rendre les plus grandes fariboles intéressantes, et qui fait qu'un homme de bon goût peut s'amuser agréablement aux Mémoires de Mme du Noyer' (1 August 1712). Du Noyer herself also mentions and addresses Van Effen in her LHG (Letter XCVI, 437-438). 


\section{The Quintessence des Nouvelles}

In 1711, Du Noyer took over the Quintessence, the bi-weekly periodical that had been created in 1689 and directed since 1710 by Nicolas de Gueudeville. She would remain the editor until 1719 , reporting on current events. ${ }^{30}$ During at least part of her coverage of the period from October 1712 until June 1713, six months in which the Treaty was being prepared and the following two months during which the effects of the Peace were felt, she was probably residing in Utrecht. Her reporting is therefore a direct interaction with this specific historical context: the peace negotiations.

Although issues were released on Mondays and Thursdays, the Quintessence was called a weekly paper ('feuille hebdomadaire') by her successor, ${ }^{31}$ as well as by Hans Bots who uses the term 'feuille' (a page/or a leaf) admitting that it has much in common with a gazette. ${ }^{32}$ The Quintessence is also termed lardon from the verb 'larder', 33 which in French combines the meaning of the term 'to lard' as enhance, embellish or give flavor with lard, but also stab, referring to political jabs in particular. Additionally, the format itself, consisting of a single and very long sheet or leaf, is reminiscent of a strip of lard. All in all, it is a onesided page with tight print, between seventy-five and eighty-five lines, with international political, societal and literary news printed in one column using both verse and prose in a serious, satirical or comical tone.

As reflected in the full title of the Quintessence, in order to pique the interest of her readers, Du Noyer intermingles other, current events, with serious world news and cogent political information, personal commentaries, anecdotes, gallant tales, moral reflections, letters (fake or real letters to the editors),

30 Her coverage of the negotiations informed her readers of breaking news in France, as well as other nations. Readers were exposed to news from many different nations and thus learned about Spain, Prussia, Sweden, Portugal, and even about the war between the Emperor and the Turks.

31 QN, nr. 44, 11 June 1719: 'successeur dans la composition de cette feuille hebdomadaire'. See also Van Dijk, 'La Quintessence après Madame Du Noyer', in Traces de femmes, 125-128.

32 Hans Bots, 'Quelques gazettes de Hollande en langue française et le Mercure Historique et politique: une analyse comparative', in Gazettes et information politique sous l'Ancien Régime, ed. Henri Duranton and Pierre Rétat (Saint-Etienne: Publications de l'Université de Saint-Etienne, 1999), 166.

33 According to Eugène Hatin, Les gazettes de Hollande et la presse clandestine aux XVII et XVIII $I^{e}$ siècles (Paris: Pincebourde, 1864), 182. The Oxford English Dictionary defines 'lardon' as 'one of the pieces of bacon or pork which are inserted in meat in the process of larding', giving primacy to that process. 
poems such as epigrams, odes, madrigals, sonnets, enigmas, even biblical references and epitaphs, ${ }^{34}$ etc. She admits that she wishes to inform and instruct but also to entertain and give pleasure to her readers (the expression she uses is; 'réjouir les lecteurs'). ${ }^{35}$ By taking full advantage of the 'larding technique', Mme Du Noyer was one of the most famous reporters and editors of this periodical. Her originality - compared to her predecessors and followers-stems from her style of reporting which is neither impartial nor impersonal. On the contrary, by being very much aware of the tastes of her readership, she is able to reconcile breaking news with personal interjections and insertion of various literary genres, using a multitude of sources in a very clever way.

The Quintessence incorporates accounts drawn from outside sources both official and semi-official. She often relies on hearsay, sometimes first hand and sometimes second hand: she would also depend on other gazettes, letters, notices both written and oral, and memoirs. This practice was actually quite common among gazetteers throughout the century, and Mme Du Noyer does not deny or hide this fact. Although she is not explicit about the origin of the information, there are often indirect references to various sources in recurrent formulas such as: 'One learns from special letters from London', 'We have received from Vienna', 'One finds out from Utrecht' or again 'One has news from Portugal through France. ${ }^{36}$ It is difficult to determine if she is referring to letters, notices, private informers, hearsay, or conversations. ${ }^{37}$ However, at times, she is more precise, actually revealing her source; for example, when she mentions the Supplément de la Gazette d'Utrecht and refers to it for more

34 Among others, Pierre Jurieu's in the QN, nr. 9, 30 January 1713, later on those of Louis XIV and Queen Anne of England.

35 QN, nr. 12, 9 February 1713.

36 QN, nrs. 4, 5, 7, 9, dated 12, 16, 23 and 30 January 1713 .

37 She must have used, for instance, the list providing information about the ambassadors, the places where they were living and the colours of their lackeys' livery: Namen, woonplaatsen en livreyen, van Haare Excellentiën, de Heeren Plenipotentiarissen, welke haar laten vinden op het Congres van een Generale Vrede t'Utrecht (Utrecht: Van Poolsum, 1712); as well as Nicolas Chevalier's Relation des fêtes que Son Excellence Monseigneur le Duc d'Ossune a données au sujet de la naissance du Prince Ferdinand de Castille (Utrecht: chez l'auteur, 1713). We thank Floortje Tuinstra, of the Utrecht Archives, for this information. Freschot, author of the Histoire amoureuse et badine [...], will use this fact in attacking her: 'Mme l'auteur avoue qu'un homme de condition lui avait fourni les mémoires [...] elle n'entend ni le latin ni le flamand dans lesquelles langues on trouve écrite l'histoire d'Utrecht' (nth letter, 264). 
details. ${ }^{38}$ In this instance, it is very difficult to determine exactly what was copied from the Gazette d'Utrecht as issues from that particular period no longer exist. ${ }^{39}$

Although the much awaited peace is the focal point of the news, many other issues and topics seemingly less important are brought to the forefront and given prominence. Emerging from behind the political and historical events of the peace treaty, a whole colourful spectrum of events is presented to the reader, albeit succinctly in the Quintessence, which would later be amplified in Du Noyer's Lettres historiques et galantes. Du Noyer writes about social, cultural and religious affairs and presents literary and dramatic criticism and short novellas in serial form. As a contemporary of Addison and Steele, authors of the Spectator (1711-12), she might have been influenced by them, especially in the way that she presents herself in her own texts as a narrator who is not completely objective.

\section{An issue of the Quintessence}

To illustrate her method and show how she constructs her narrative, interweaving seemingly heterogeneous topics and genres together, let's examine the issue published on Thursday, 12 January $1713, \mathrm{n}^{\circ} 4$. It starts with: 'On mande d'Utrecht qu'il y eut lundi [9-1] un congrès des Ministres des Alliés à l'Hôtel de Ville, après quoi ces Seigneurs furent tous chez son Excellence Mgr. le Comte de Tarouca [...] qui leur donna un Festin magnifique [...]'. The feast being in honour of the birth of the prince of Brazil, Du Noyer comments on this birth as being a good augury for the peace negotiations as 'il est arrivé trois événements considerables à sa naissance':40 (1) the suspension of war between Portugal, France and Spain, (2) the withdrawal of the Spanish forces at the siege of Campo Major, and (3) the arrival in Lisbon of the boats from Brazil loaded with

38 QN, nr. 5, 16 January 1713: 'On peut voir une description de tout cela dans le supplément de la Gazette d'Utrecht, et nous n'en parlerons que succinctement'.

39 The Gazette d'Utrecht actually was entitled at the time Journal d'Utrecht. According to Sgard's Dictionnaire des journaux, there remain only five issues, but they do not cover this particular period. <http://dictionnaire-journaux.gazettes18e.fr/journal/o531-gazettedutrecht $>$.

'One sends from Utrecht that there was a meeting of allied ministers in the city hall, after which they all went to a feast thrown by the first plenipotentiary of the King of Portugal, the count of Tarouca, in honour of the birth of the Prince of Brazil [...] three considerable events have taken place'. 


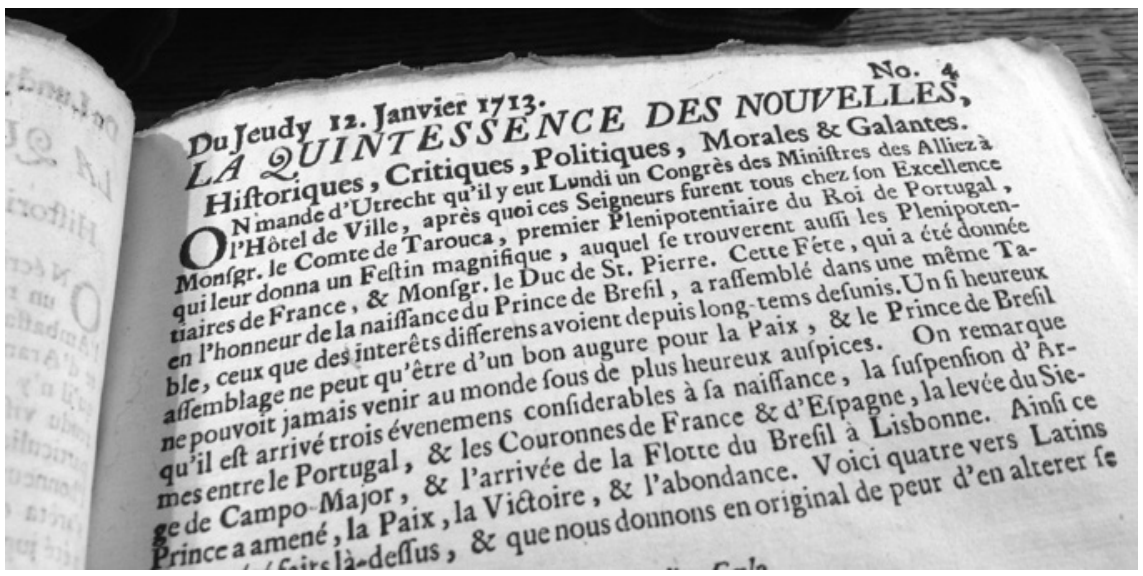

FIGURE 5.1 Picture showing the opening paragraph of Quintessence des Nouvelles for the year 1713, issue d.d. January 12th, about the feast organized by the count of Tarouca of Portugal in celebration of the birth of the Prince of Brazil.

Рното H. GOLDWYN

precious goods. She therefore concludes that the prince has brought peace, victory and abundance. This is followed by four verses in Latin in honour of the prince.

Switching abruptly, she reports on the social occasion and makes auctorial interventions by commenting on the beautiful people assembled at the party: 'Il eût été à souhaiter qu'on eût pu peindre toute cette belle assemblée [...] lorsqu'elle était à table [...]. Après le dîner il y eut Comédie, dans laquelle les Acteurs se surpassèrent'.41 In addition, she describes at great length the décor and the excellence of the host, the count of Tarouca, in particular his attentiveness to his lady guests. Continuing in the same vein, she reports that the following day there was a ball, listing all those who attended and those who did not. She concludes by stating with a hint of irony that: 'On est si fort occupé de plaisir à Utrecht, qu'on n'y parle pas beaucoup d'affaires. ${ }^{42}$ However, she reports that it is believed that once a much-discussed skirmish between Count Rechteren $^{43}$ and M. Mesnager has been settled, the general conference will

41 QN, nr. 4, 12 January 1713: 'it would have been worthwhile to paint this beautiful assembly while sitting at the table $[\ldots]$ dinner was followed by a play, where the actors surpassed themselves....

42 Ibid.: 'One is so busy with pleasure in Utrecht that one does not talk much about affairs'.

43 An altercation occurred between the lackeys of Count Rechteren (Netherlands) and M. Ménager (the French plenipotentiary). A vulgar gesture made by Ménager's valet degenerated and brought the peace conference to a halt. 
resume. This altercation literally brought the peace negotiations to a standstill. It is interesting to note here that the mention of this quarrel later became an amplified sequence with juicy details in the Lettres historiques et galantes. ${ }^{44}$ Moving on rapidly, she introduces a song in verse about the Peace that the queen of England champions with the assistance of Lord Strafford, her equerry. It is entitled: 'Quand tout est calmé sur la terre, etc.' ${ }^{45}$ She ends this issue by describing the medal of the city of Utrecht featuring two towers, and their significance.

As we clearly see here, she juxtaposes the political and historical significance of the treaty with items that might appear frivolous at first sight, such as meticulous and recurrent accounts of the lavish display of the occasion, including detailed portrayals of the festivities (balls, masquerades, dinner parties, theater productions...), descriptions of the carriages used by the ambassadors, the clothing they wore, comments about the ladies which smack of gossip columns or tabloid journalism-before the word was even invented. At a time when reading papers was fashionable and printing periodicals was a lucrative business, the peace negotiations and the way they are represented through parties, banquets and celebrations are particularly appealing to an educated circle of readers. Du Noyer demonstrates that the assemblies followed by parties and feasts served as crucial spaces that facilitated interaction and the cross-pollination of ideas, bringing together negotiators, ambassadors, plenipotentiaries, emissaries and showcased their negotiating prowess. Their social skills in diplomacy were thus highlighted at balls, banquets, musical performances, and plays. All these events reflect the power and wealth of the kings and rulers the plenipotentiaries represented. ${ }^{46}$

As suggested earlier, although Mme Du Noyer might have been inspired by other contemporary writers, and might have even emulated some of them, it seems that her reporting style-the clever and entertaining collage she champions-is very much her own. She carries this technique a step further by rewriting, reworking, and dramatizing the material already used in the Quintessence in the sixth volume of the Lettres historiques et galantes, giving it a new life and reaching a wider and more international reading public.

It is recounted in a highly comical and satirical tone in Letter XCIII, 145.

45 'A song on the minuet air of Hesione. When everything has become calm on earth'.

46 See lengthy descriptions in QN nr. 15, 20 February 1713 of the dinner party thrown by the count of Tarouca of Portugal during which the play Rodogune by Pierre Corneille was performed 'dans laquelle les acteurs se surpassèrent et [...] Colombine fit des merveilles et eut des applaudissements infinis dans le rôle de Cléopâtre', or again in QN nr. 16, 23 February 1713 the marvelous party organized by the Earl of Strafford (the British ambassador). 


\section{The Lettres Historiques et Galantes}

The strong relationship between the Quintessence and the Lettres Historiques et Galantes, most probably directly related to the precariousness of Du Noyer's financial situation, provides us now with the possibility of showing the author 'at work': the Quintessence reporting became a 'first draft' of the more lasting publication which were the Lettres. This 'auto-plagiarism' did not concern only the Peace reporting but was characteristic of her work as has been presented in more detail elsewhere. ${ }^{47}$

On 15 May, one month after the signature of the Treaty, the Quintessence itself announces the publication of vol. VI of the Lettres historiques et galantes:

Le Sieur Pierre Husson, Marchand libraire sur le Kapelbrug à La Haye, avertit le public qu'il vendra au premier jour le sixième volume des Lettres Historiques et Galantes, par Madame de C...Ouvrage curieux, dans lequel on trouve les plans et la description de la Ville d'Utrecht, une relation de ce qui s'y est passé de plus particulier, pendant le Congrès avec les Armes des Plénipotentiaires au dit Congrès. ${ }^{48}$

It contains twenty letters (LXXXIV-CIII, some of them quite long) dedicated to the Peace Congress and the events surrounding it. Du Noyer-while not mentioning herself on the title page of this publication - maximized the benefit of the material she had accumulated over 1712 and 1713, when publishing daily news about 'Utrecht'. By repurposing her opportune data, she published quickly what seems to have been the first substantial account of the Peace conference-apparently before the one by Casimir Freschot entitled Histoire du Congrès et de la Paix d'Utrecht, and also before Augustin (?) Freschot's Histoire amoureuse et badine: the latter clearly manifests feelings of jealousy in his (already quoted) eleventh letter. ${ }^{49}$

47 Cf. n. 19. Commemorating the Peace of Utrecht provided an interesting occasion to get back to the question discussed more generally earlier.

48 'Pierre Husson, Book seller at the Kapelbrug in The Hague, announces that he will sell the sixth volume of the Lettres Historiques et Galantes, by Madame de C... Interesting work in which are to be found maps and the description of the city of Utrecht, and a relation of what happened during the Congress, with the arms of the Plenipotentiaries of the Congress'.

49 This is also Erik Tigelaar's conclusion in his comments on the translation of the Histoire amoureuse et badine (152). See also n. 14. 
From the series of Quintessences, published roughly between October 1712 and April 1713, i.e. over fifty issues in most of which there was some information related to the 'Peace process', she derived twenty letters (about four hundred pages), some of which included lists of names and geographical and historical descriptions of Utrecht. In her recent edition of the Lettres Historiques et Galantes (2012), O'Connor did not include them for this very reason. As she specifies, many long passages of these letters had been taken from Du Noyer's own Quintessence. ${ }^{50}$ However, this 'auto-plagiarism' is exactly what interests us now, and the point is to show how Du Noyer proceeded while adapting the material from her Quintessence, making it correspond to her fictional character who walks around Utrecht, as did the author, writing down her impressions for the Parisian friend who is so eager to read them. ${ }^{51}$

While fictionalizing her own self, she needed to create, in her text, a bit more coherence between the narrator and narratee than had existed between the journalist and her readers. ${ }^{52}$ This coherence was created by referring to the friendship that supposedly existed between the two correspondents, who remain anonymous, and by their common interests: they feel 'linked' to each other in being enthusiastic readers of the Quintessence and fans of 'the lady who wrote the Quintessence' (Du Noyer's name is not mentioned). Furthermore, both are heavily interested in what the other is going to writeand much less in each other's personal circumstances. There is no reference to any family life, for instance. In a way, these letters are less personal than what Du Noyer wrote in the Quintessence as here she supposes her friend curious to know everything, meaning everything that might happen and be of any local, national or international relevance. Even the history of the city of Utrecht and official documents, containing lists of the ambassadors' names, are included for instance in letters XCI and XCV, respectively.

Framing the Peace narrative within a fictional correspondence had some interesting consequences, linked to the relationship with time. While the Quintessence was published twice a week and the issues needed to be filled up anyway, on the contrary, the letters exchanged by the two ladies remained undated. Sometimes as a journalist she clearly had difficulties because of the too large or too small amount of 'nouvelles', while the 'lardon' format of the

\footnotetext{
$50 \quad$ O'Connor 2012, p. 29.

51 Her correspondent in Paris approves the liberty she is taking with chronology (Letter CIII, 204).

$5^{2}$ And also, in fact, between narrator and the 'characters' described: she suggests, for instance, that she had been invited especially by the count of Tarouca (Letter XCVIII, 32).
} 
Quintessence remained identical: in such cases she tended to use smaller characters or, if need be, add some verses or enigma at the bottom. In the Lettres historiques et galantes this problem does not arise: the length of the Utrecht letters is completely dependent on the quantity of material she wants to present, and fluctuates between twelve and fifty pages (resp. letters XCVI and XCVIII).

The passing of time is also handled differently - a clear example of which might be the repeated announcements in the series of Quintessences of events expected to happen, first in the future, then next week, and, finally, on this very day. For instance, when Strafford was expected to come back from London to Utrecht, the tension grows over a period of two months:

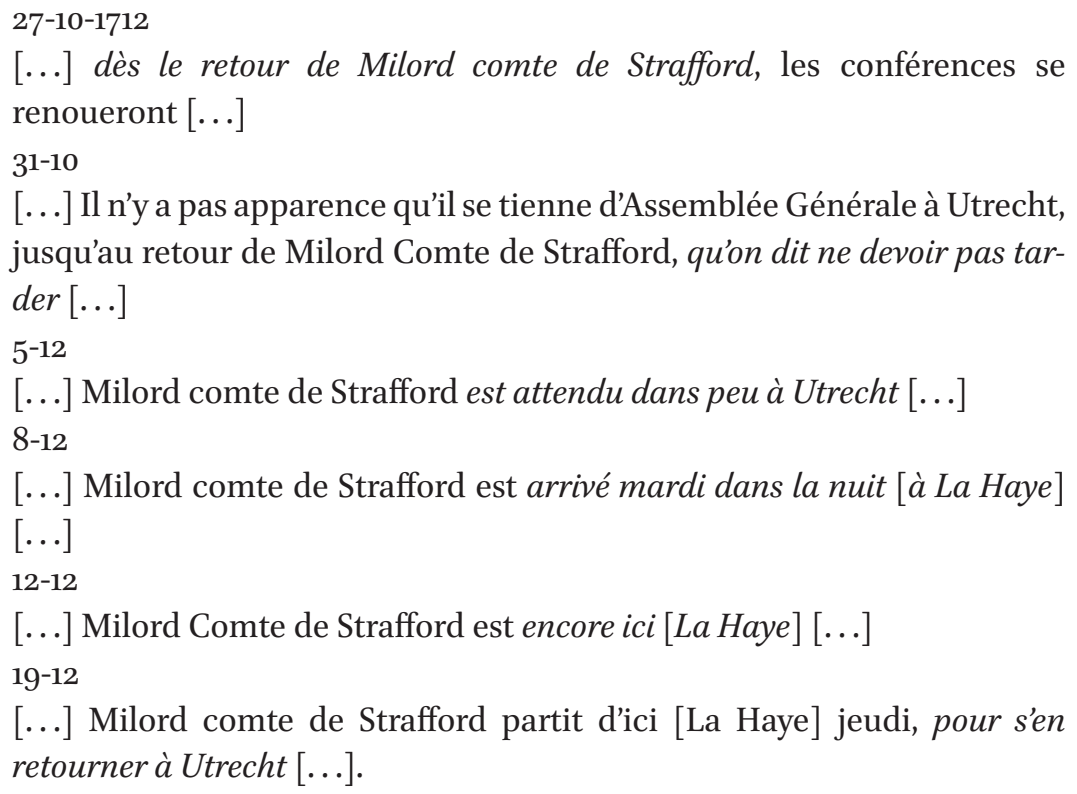

[...] Il n'y a pas apparence qu'il se tienne d'Assemblée Générale à Utrecht, jusqu'au retour de Milord Comte de Strafford, qu'on dit ne devoir pas tar$\operatorname{der}[\ldots]$

Once Strafford is back, there will be a 'Congrès général', and things will happen: 'les affaires iront à présent plus vite qu'elles n'ont été. 53

In the (undated) Lettres historiques et galantes, such an event tends to be mentioned only once but then in more detail, as in Letter XCVIII:

53 'Once S. will be back, the conference will start again'; 'There will be no General Assembly in Utrecht, before S. will be back, which should be soon'; 'S. is expected soon in Utrecht'; 'S. arrived in The Hague last night'; 'S. is still in The Hague'; 'S. left The Hague Thursday to go back to Utrecht'; 'Things will now be quicker than they were before'. 
[...] Milord Strafford est de retour d'Angleterre, on y va travailler à grand force [à la paix] [...] c'est lui qui lui donne la main pour la conduire à Utrecht. Du moins c'est la pensée de ces Vers, qui ont paru dans la Quintessence. ${ }^{54}$

Indeed on 12 December, Du Noyer had included these verses in the Quintessence; establishing the link without mentioning the identity of the author, they reappear here:

Strafford paraît à nos yeux

Tout brillant des faveurs d'une puissante Reine.

Il va faire voler des Cieux

La Paix sur ces climats. C'est lui qui la ramène.

$[\ldots] .^{55}$

The grouping together-on this and similar occasions - of mentions which originally were spread over several weeks allows each letter of Lettres historiques et galantes to be much more individual than was the case for the Quintessences, where a certain degree of repetitiousness was difficult to avoid.

\section{A Feminine Perspective}

The poem celebrating Strafford's return to Utrecht also highlights Du Noyer's interest in Queen Anne, the 'puissante Reine'. This interest was already visible in the Quintessence but is now further expanded in the Lettres: the narrative instance is framed much more clearly as a female person, addressing a female narratee, both interested in other women, be it Queen Anne, ${ }^{56}$ the Spanish queen, ${ }^{57}$ the 'charmante Dauphine', ${ }^{58}$ Anna Maria van Schurman, famous learned woman from Utrecht, ${ }^{59}$ or others. Famous women are not the only

54 'Milord Strafford came back from England, one will work hard now for preparing peace [...] Strafford is the one who will invite her to come to Utrecht. At least this is suggested by these verses which were published in the Quintessence'.

LHG, Letter XCVIII, 6: 'Strafford appears in front of us / ablaze by the favours of the mighty Queen. / He will make Peace fly toward our climates. He is the one who brings her back'.

56 See letters LXXXVIII, 285; LXXXIX, 291; XCVIII, 17-20; CVIII, 353.

57 LHG, Letter CI, 170.

58 LHG, Letter LXXXVI, 278.

59 LHG, Letter XCI, 303; XCII, 333. 
striking figures: in some of the fictional items we also find young, smart girls as heroines, manifesting strong will and character. ${ }^{60}$

Identification with 'femininity' and the private life of women is of equal concern to both ladies as are their possibilities for happiness in marriage. It is interesting to see how Du Noyer has seized the opportunity to discuss this subject in the middle of a political event dominated by male protagonists, which nevertheless led to those social gatherings announced and commented upon in the Quintessence.

The Parisian correspondent in the Lettres historiques et galantes is assumed to take an interest in the doings of Mylord Albemarle, as seen here:

Il est à présent à La Haye avec Milady son épouse, dont il est toujours aussi amoureux qu'il l'était avant son mariage, dont la date est pourtant de près de douze ans. Malgré le mauvais usage que la dépravation du siècle a établi, il ne lui a point donné de concurrence ni de coadjutrice, et il l'aime avec tant d'ardeur, que lorsqu'elle a été en couches à Tournai, dont il est Gouverneur, toutes les cloches ont été muettes pendant quinze jours, comme elles le sont en France à la fin de la semaine Sainte. Cela s'appelle être un bon mari, et pousser la tendresse conjugale au suprême degré. 61

This quotation, showing a tender husband creating the best possible conditions for his wife who is about to give birth, is especially compelling in light of the aforementioned other-male-reporting about the Peace congress: Freschot's Histoire amoureuse et badine du Congrès et de la Ville d'Utrecht. Here the author's focus ${ }^{62}$ is completely upon the 'concurrences' and the 'coadjutrices' of married men who are looking for romance in Utrecht, while their wives are staying at home.

6o For instance: LHG, Letters XCI, 304; XCIV, 405.

61 LHG, Letter XCIII, 330-331 (our italics): 'He is now in The Hague with Milady his wife, with whom he is still in love at the same degree as before his marriage, which dates back to twelve years ago. In spite of the bad uses due to the depravity of our times, he did not give her any rival, and still loves her with such an ardor, that when she was about to give birth in Tournai (where he is the Governor), all bells have been silent during a fortnight, as they are in France during the Holy week. This shows his being a good husband, and pushing tenderness to the highest degree'.

See note 14 about the identity of the author. 
By promoting Albemarle as the 'bon mari [qui pousse] la tendresse conjugale au suprême degré', Du Noyer (or her imagined Lady from Utrecht) is clearly keeping her distance from 'la dépravation du siècle' which is so omnipresent in the Histoire amoureuse et badine [...], whose author is principally interested in scandals related to connections established by foreign visitors. These were not only busy discussing the Treaty in the Utrecht Town Hall but also engaging with Utrecht's 'official' or improvised prostitutes, daughters of wig makers and tavern owners-Freschot formulated explicitly that these illicit contacts between the plenipotentiaries (or their servants) with Utrecht ladies (or their servants) were the subjects that his intended (male) readers wanted to be informed about. ${ }^{63}$

Du Noyer's 'Lady from Utrecht' does not at all suppose that her Parisian friend wants to read about this. On the contrary, she insists upon presenting the very respectable spouses who accompany their husbands the ambassadors, and she creates occasions that allow her to express her approval of matrimonial happiness and any good relationship between husband and wife-be it Mylord and Lady Albemarle, or other couples. This tendency had already been suggested in the Quintessence but seems clearer still in the Lettres, thanks to the possibility, or even the need, of putting together information that belongs together. In that sense we might suggest that Du Noyer adopted here a more recognizably 'feminine' point of view, insisting upon the qualities and the merits of those spouses who came to Utrecht and who in some cases would seem to have played prominent roles:

Il y a assemblée certains jours de la semaine chez les Ministres qui ont ici leurs épouses avec eux, et chez d'autres personnes de considération de la ville. C'est dans ces Assemblées que l'on voit briller les belles Ambassadrices de Prusse, Madame la Comtesse de Dönhof, et Madame Marchal. Ces deux Dames font l'admiration du Congrès, et pourraient, avec raison, faire celle de tout l'Univers; car on n'a jamais rien vu de plus charmant.

And she 'proves' the fact by reproducing 'des vers qui ont paru sur la Quintessence', concerning 'la Comtesse de Dönhof':

63 'Vous êtes las, me dites-vous Monsieur, d'entendre parler de Traité de Paix [...]. Vous voudriez que je vous parlasse un peu des intrigues amoureuses, et que je vous fis l'Histoire Badine de ce congrès' (Lettre I, 1). 
La Prusse féconde en beauté

Nous en fait voir ici l'élite.

La Seine sur ses bords autrefois tant vantées,

N'eut rien d'égal à leur mérite. ${ }^{64}$

The same Lettre presents (431-432) a similar poem praising Mme Marchal, which had also been included in the Quintessence $\left(3^{1-10-1712) . ~ A t ~ t h e ~ e n d ~ t h e ~}\right.$ 'Utrecht Lady' specifies:

Tout ce que je puis vous assurer, c'est qu'il n'entre point de flatterie làdedans. Je parle pour avoir vu, et l'on peut dire qu'il n'est rien de plus charmant que ces deux dames-là. ${ }^{65}$

In a more general sense, the Utrecht Lady—or perhaps the author-is showing herself off as a well-behaved, lady-like person, a foil to the bad reputation $\mathrm{Du}$ Noyer had gained. For us today, it is interesting to see this female perspective in contrast to the male reporting highlighted during the 2013 commemoration. ${ }^{66}$

\section{Conclusion}

Mme Du Noyer refers often to her relationship with her educated audience, especially her female readership. In the eighteenth century, women became avid readers of periodicals where news and other topics were presented in an appealing and not overly scholarly tone. Both the Quintessence and the Lettres historiques et galantes reflect that concern. Time and again, she reminds us with great irony and wit that she is neither a historian nor a theologian or a

64 'One gathers certain days of the week at the homes of the Ministers who brought their spouses, and those of other persons of importance in the city. In these meetings we see the brilliancy of the beautiful Ambassadresses of Prussia, Madam the Countess of Dönhof, and Madam Marchal. These two ladies are admired all over the Congress, and could even be admired all over the universe; there was nothing more charming to be seen. [...] Prussia, fertile in beauty, shows us here its elite. The Seine so much applauded for this reason, does not possess anything similar to their merits. These verses initially published in the QN, 3 November 12, reappear in the LHG (Lettre XCV, 431).

65 'I can assure that there is no flattery here. I have seen and concluded that there is nothing more charming than these two ladies'.

66 For instance in the exhibition organized by the Utrecht Archives (HUA), which was entitled 'High wigs, low amusement'. 
specialist in rhetoric but a woman writing and wanting to share with other women the most important events taking place.

Thus, weaving in and out of two different genres which found their way into France and the rest of Europe, a bi-weekly paper and a fictitious epistolary exchange between two female correspondents, she often rewrites, reworks and dramatizes the same material, especially current events, with a different twist and in a different style. It is at times difficult to differentiate where current events stop and fiction begins, especially when she interjects or makes auctorial interventions, offers metadiscourse and recounts anecdotes in the third person singular ['on'] in the Quintessence and in the first person in the Lettres historiques et galantes ['je']. It is precisely this fictionalization of the news or the subjectification of political events and the devices used that is of interest to her reader. Although she might appear to come across as a political and cultural commentator, staging herself as an eye witness, the historical and the political are most often spiked and subverted by the social and the literary. 